\title{
In Pursuit of Teachers' Views on the Use of Textbooks in Their Classroom Practice
}

\author{
Mar Aswandi Mahadi ${ }^{1} \&$ Masitah Shahrill ${ }^{1, *}$ \\ ${ }^{1}$ Sultan Hassanal Bolkiah Institute of Education, Universiti Brunei Darussalam, Jalan Tungku \\ Link, Gadong, BE 1410, Bandar Seri Begawan, Brunei Darussalam \\ *Corresponding author: Tel: 673-246-3001 E-mail: masitah.shahrill@ubd.edu.bn
}

Received: May 15, 2014 Accepted: June 10, 2014 Published: June 23, 2014

doi:10.5296/ije.v6i2.5637 URL: http://dx.doi.org/10.5296/ije.v6i2.5637

\begin{abstract}
The main purpose of this study was to investigate the views of the teachers on the use of primary history textbooks in their history classroom lessons in Brunei Darussalam, and whether their views were aligned with the aims and objectives of history education at the primary levels. Interviews with five teachers were conducted and the interview data were categorised into five broad conceptual themes related to the use of textbooks; priorities of the use in the classroom, perceptions in the use for lesson preparation, interpretations of the history curriculum in the classroom, relationship with the use and aligning it with the aims and objectives of the curriculum, and finally, the views about textbook content. The findings revealed that there exists an apparent lack of knowledge of the sample interviewed in interpreting the aims and objectives of the history curriculum in their classroom practice. There may be implications on the quality of students' learning of history at the primary level if teachers do not have sufficient understanding on the needs of the curriculum.
\end{abstract}

Keywords: history; textbooks; primary; teachers; interviews 


\section{Introduction}

The textbook is one of the important resources in the process of teaching and learning. According to Hummel (1988), the textbook is an instrument perfectly adaptable to every individual's own rhythm. With the aid of the textbooks, the pupil recapitulates, assimilates and further internalizes what was learnt in class. The textbook can also provoke questions and induce a pupil or pupils to supplement the information it contains. Moreover a good textbook encourages the pupils to think and stimulates critical reflection.

According to Santhiram (1997), the socialization of pupils to the aims and goals of education in a country takes place through curriculum. The curriculum provides the focus for teaching and learning activities and thereby occupies a central role in the formation of fundamental attitudes and images that provide the basic core of values. The textbook assumes a key role because it is a dominant form of curriculum material. It is the key classroom teaching aid in schools. A survey in the United States showed that $75 \%$ of the time elementary and secondary school pupils are in the classroom, they are using the textbook. The figure rises to $90 \%$ for homework (Harber, 1989).

Altbach et al. (1985) stated that the power and influence of the textbook lies within the printed words and that it is the key element in the educational process. Textbooks are central to schooling levels. The textbook is the tool for instruction and its potentials, limitations and actual use are conditioned by features of the total system. With that, textbooks without doubt carry intrinsic values and the historical mirror on which the nation wishes to see it reflected. The selection and legitimizations of content in the textbook are seen as vital to national needs.

However, dramatic changes is happening in technology where electronic media are a common place and comfortable part in academic life and raise the question of how textbook fit into students' cultural and learning environment. Bierman et al. (2006) argued that textbooks are not dead but their roles and appearance are changing fast. They predicted that the textbook's function would be as a guide, interweaving and coordinating a variety different learning exercise and organizing hub of an integrated learning environment where the students experience is the key. Bierman and colleagues (2006) added that "the goal is to retain the core stability and authority that make the textbook so valuable while at the same time providing the flexibility, timeliness, and inquiry-focused approach that the web and other electronic resource provide” (p. 306). And this was evident in a study by de Oliveira and colleagues (2014) where even with the latest advancements in teaching resources, such as e-textbooks, are introduced teachers still need to scaffold the entirety of the classroom learning effectively to their students. Teachers are also encouraged to be reflective in the best use of primary sources (for example, the internet archives or the commercially available earning packages) in order to engage students in history classes (Barton, 2005).

Brunei Darussalam (hereafter referred to as Brunei) itself has a textbook dominated culture in its schools. And thus, the impact of textbooks on achievement is self-evident. The history textbook is one of the important supporting material in teaching and learning in Brunei that was given by the Curriculum Development Department (CDD) of the Ministry of Education for the teachers and the students. The availability of resources for history teaching in Brunei primary 
schools is the responsibility of the CDD of Brunei. The aims are to give the awareness that the pupils should know about past history for the preparation of the current and future event. In Brunei, the teaching curriculum of all subjects in Government schools is centralized. This means that every school uses the same syllabuses and textbooks. Hence, the most common history teaching materials in upper primary school are the textbooks and workbooks. This is also evident for other subjects, such as mathematics, where $95 \%$ of the mathematics lessons in the lower secondary lessons in the Brunei data used either a textbook or worksheet as the most used resources (Shahrill, 2009). Alternative assessments (see Nor \& Shahrill, 2014) and their learning engagement (see Wahid \& Shahrill, 2014) were also investigated at the pre-university levels. For secondary science students in particular, they relied $100 \%$ on using textbooks as the only sole reading material in their classes (Yong, 2010).

As stated by CDD (2002), the main aim of publishing and producing the history textbooks for primary 4, primary 5 and primary 6 is to produce textbooks that reflect the culture and identity of Brunei so that pupils can better understand the history and to gain knowledge of their own country. The content provided also encourages various activities in teaching and learning history. In general, they cover a very large period of time from the primitive eras to the middle of the $19^{\text {th }}$ Century. The contents are divided into chapters and sections according to historical periods and arranged in chronological order. The history textbooks focused mainly on Brunei history. World history is also covered but only within the context of its relationship with Brunei history which includes the neighboring nations and Brunei's relationships with the European countries. The textbooks generally consist of texts, illustrations, pictures, maps, figures, tables, glossaries, and suggested extra activities for the pupils to do at the end of each chapter. There is a uniqueness that appears in the history textbook for the Upper Primary level in Brunei because in each introduction of every chapter, there are quotes from the Quran. This shows an indirect connection with the moral or values of the stories presented in each chapter.

The general aims of history education at primary levels in Brunei are to create a common perception of the past; to appreciate the contribution of the past towards the development of mankind; to inculcate pupils' sense of national identity through the study of history as a basic foundation to love their country and to promote the interest in learning history. The objectives are to develop an understanding of chronological sequence; to develop consciousness and awareness of continuity and change towards their country through the study of history; to provide a change for the pupils to compare and contrast and appreciate the significance of similarities and differences and make simple informed judgment about the past such as cause and effects; to acquire basic skills in collecting, organizing, recording and presenting information; to develop basic skills in recognizing, understanding and using chronological convention such as $\mathrm{BC}, \mathrm{AD}$, decade and etc; begin to assess the value of stories and simple written sources as piece of evidence (CDD, 1990).

The aim of this study is to explore how teachers in Brunei schools use and interpret the aims and objectives of history lessons and deliver them through the use of textbooks. By conducting this study, the researchers hope that it will benefit certain individuals or groups to improve the teaching and learning in history, specifically in writing and producing textbooks or delivering the contents of historical texts in history classroom. It is important to note that 
the education system in Brunei has recently undergone a major educational reform known as the National Education System for the 21st Century or SPN 21 Sistem Pendidikan Negara Abad Ke-21 (Mundia, 2010; Omar et al., 2014; Salam \& Shahrill, 2014). Even within these early stages of curriculum changes in all educational levels, findings from this study may benefit curriculum developers in their on-going process of improving the primary syllabus for all subjects. Furthermore, this study and the findings will form a basis on which extended research or researches can be conducted.

\section{Research Question}

This study was guided by the main research question "What are the history teachers' views in the use of textbooks in their classroom practice?”

\section{Methodology}

A qualitative approach was used in data collection where five teachers were interviewed to collate their views on the use of textbooks in their classroom practice. The teachers were selected based on their willingness to participate in this research and also from the recommendation from the principal. A semi-structured interview was used. The interview was designed to obtain data on the respondents' opinions or views, interpretations, perceptions, problems and practices regarding the usage of the Brunei upper primary history textbooks. All the interviews were voice-recorded with the respondents’ permission and transcribed.

Provided in Table 1 below is the demographics of the teacher sample.

Table 1. The teacher demographics

\begin{tabular}{|c|c|c|c|c|c|}
\hline \multirow{2}{*}{ Background } & \multicolumn{5}{|c|}{ Brunei Teachers (BT) } \\
\hline & BT1 & BT2 & BT3 & BT4 & BT5 \\
\hline Age & 35 & 39 & 41 & 43 & 39 \\
\hline Gender & Female & Female & Female & Female & Male \\
\hline $\begin{array}{l}\text { Highest professional } \\
\text { qualification }\end{array}$ & $\begin{array}{l}\text { Diploma in } \\
\text { Education }\end{array}$ & $\begin{array}{l}\text { Diploma in } \\
\text { Education }\end{array}$ & PGCE & $\begin{array}{l}\text { Diploma in } \\
\text { Education }\end{array}$ & $\begin{array}{c}\text { BA in } \\
\text { Education }\end{array}$ \\
\hline $\begin{array}{l}\text { Duration of teaching } \\
\text { experience }\end{array}$ & 15 years & 14 years & 18 years & 12 years & 9 years \\
\hline $\begin{array}{l}\text { Duration of teaching } \\
\text { history }\end{array}$ & 4 years & 4 years & 7 years & 2 years & 3 years \\
\hline History level taught & Primary 6 & $\begin{array}{l}\text { Primary 4, } \\
5 \& 6\end{array}$ & $\begin{array}{l}\text { Primary 4, } \\
\quad 5 \& 6\end{array}$ & $\begin{array}{l}\text { Primary 4, } \\
\quad 5 \& 6\end{array}$ & Primary 5 \\
\hline
\end{tabular}

\section{Results and Discussions}

The data analyses of the interviews cover five broad conceptual themes and presented in each sub-section as follows. 


\subsection{The Level of Priorities in using Textbooks in the Classroom}

The teachers were firstly asked 'How often do you use the Textbooks?' All the teachers said they always use the Textbook when teaching history subject in the classroom. However, one teacher (BT 5) responded a higher level in priority in using the Textbook.

The textbook is a 'core'. It is essential and a must.... (BT 5)

\subsection{Teachers' Perceptions in the use of Textbooks for Lesson Preparation}

In order to find out teachers' perceptions in the use of textbooks in terms of preparing their lessons, they were asked, 'How do the Textbooks help you in preparing your history lesson?' The teachers responded according to their personal opinions. Their opinions can be categorised into six categories.

The first opinion was as a reference. Two respondents were cited in this category. The examples of the respondents' answers are presented below.

...the textbook also contains many important pictures like "Kris Si Naga" and "Peralatan Gendang Di Raja” which could be found... (BT 1)

Before teaching, I would refer to the textbook and look at its contents... (BT 2)

The second opinion was as teaching aids. Three respondents were cited in this category.

...the textbook also contains many important pictures like "Kris Si Naga" and "Peralatan Gendang Di Raja” which could be found... (BT 1)

...if there is something useful, like pictures, for me to use as my teaching aids, I would take it and enlarged it... (BT2)

...this book we can produce teaching aids like facts and pictures... (BT3)

The third opinion was to determine the objective of the lesson. Only one respondent was cited in this category.

I used the textbook and refer to the syllabus on what objectives to be achieve... (BT4)

The fourth opinion was to help to get the facts and one respondent was cited in this category.

The textbook helps me to get the facts and important points... (BT4)

The fifth opinion was to highlight the important facts and emphasized the facts in the classroom. One respondent cited in this category.

The textbook help me to get the facts and important points that should be highlighted during the lesson... (BT4)

And the final sixth opinion was as a guideline. One respondent was cited in this category.

I always follow the book as my guideline... (BT5) 
4.3 The Teachers' Interpretation of the Brunei Upper Primary History Curriculum in the classroom when using the Textbooks

In the interview, the respondents were also asked several questions to find out their interpretation of the Brunei upper primary history curriculum when they were using the Textbooks. Provided below are the summaries of the interview responses and given in parentheses are the number of teachers whose interpretations matched with the summarised themes.

1. The textbooks do not include stories that relate to the common people who had scarified themselves for their country (3).

2. The contents of the textbooks portrayed more on the contribution of the upper rank (4).

3. The textbook placed less emphasis on the economical and social development (2).

4. The content of the textbooks developed consciousness and an awareness of continuity and change towards their country through the study of history (3).

5. The content in the textbooks is effective in making the student to appreciate the contribution of the past (4)

6. The objectives of the history lesson can instill nationalism and patriotism (4).

7. The objective of the history lesson can be effective in increasing the value of loyalty towards the official religion, nation and the state (4).

8. The content of the textbook is less effective in inculcating mutual understanding between international relationships among countries (4).

9. The content of the textbook can effectively broaden the knowledge of the students concerning the other countries (3).

10. The objective of the history lesson in Brunei can instill the national integration amongst the young people (2).

11. Nationalism is less emphasized in the textbooks (4).

12. Citizenship is less emphasized in the textbooks (3).

13. National integration is less emphasized in the textbooks (3).

14. National matter is emphasized (3).

15. Relationships between the neighbouring countries are less emphasized (3).

16. Relationships with international countries are less emphasized in the textbooks (3).

17. The aspect of globalization is less emphasized in the textbooks (4).

18. Colonialism is less emphasized in the content of the textbook (5). 
19. Few aspects of development of global history in the Textbooks (4).

20. Few local history and was less emphasized in the textbooks (3).

21. Few aspects of history about relationships with neighbouring countries and was less emphasized (3).

22. The content that relates to the western colonization is less emphasized and scarce (3).

23. The content related to the early development of Brunei is adequate (4).

24. Few aspects of early development of Brunei in international history (3).

25. The aspects of Islamic influence and the cultural development in South East Asia are very scarce in the content of the textbooks (5).

4.4 How Teachers Relate the History Lesson using the Textbook with the Aims and Objectives of Brunei Primary History Curriculum

The teachers' opinions in relating the history lesson using the textbooks with the aims and objectives of Brunei primary history curriculum were recorded and given into five categories as follows.

The first opinion was by following the facts written from the textbooks.

I just follow the teaching guide provided by the Curriculum Development Department on how to teach the topics in the textbook... (BT1)

There are stories found in the Primary 6 textbook about important people who were willing to sacrifice themselves... (BT 4)

There are topics in the Primary 6 textbook, like why the size of Brunei is small? It is related with topics about James Brooke's arrival in Brunei... (BT5)

The second opinion was to relate the topics with historical places.

Then in "Kota Batu", though the historical place is almost vanished, we still can see the fortress. We can also visit museums, cemeteries, etc... (BT1)

In order to make my students to be interested with this topic, I can bring them outside from the classroom, like visiting Sultan Bolkiah's burial... (BT2)

The third opinion was to relate with historical events.

Another example is the Royal weddings... (BT1)

The fourth opinion was using teaching methods.

In order to make my students to be interested with this topic, I can bring them outside from the classroom, like visiting Sultan Bolkiah's burial... (BT2)

Projects usually made during primary 4 e.g. about "My history”... (BT 3) 
After I finish teaching my students on one topic, I would give them exercises and oral quizzes. I would also ask them to prepare questions by themselves, which each of them would later go to the front of the class and ask his or her question to the rest... (BT4)

...ask the students to collect facts and artefacts for projects, where students can visit the museum or to the related area... (BT5)

The fifth opinion was using teaching aids.

I just teach them using the textbook... (BT3)

\subsection{Teachers' Views about the Contents of the Textbooks}

Teachers' views about the contents of the textbooks were collated and summarised into six categories. The first opinion was to correct the mistakes of the facts (two teachers were cited in this category). The second opinion was to cut the irrelevant facts (two teachers), two respondents stated that the textbooks should add more pictures, three respondents said that the textbooks should add more relevant facts and one respondent requested that there should be one guidance book for history teachers to guide them to use the textbook to teach history subjects.

\section{Conclusion}

The interviews revealed that most of the respondents showed relatively few inadequacies in knowing how to interpret the aims and objectives of Brunei history curriculum. Most of the respondents simply followed the facts stated in the textbooks and their knowledge on the aims and objectives of the Brunei history curriculum was very minimal. Teacher interpretation of the curriculum is crucial. In addition, Wakefield (1998) stated, "by examining textbooks and the way that teachers have used them, we can make inferences about the educational problems which not only gave rise to textbooks, but which have encourage their development” (p. 2). Hence history teachers should know how to translate and interpret these aims in the lessons using the materials provided by the ministry.

From this study, there exists an apparent of lack of knowledge among the history teachers to interpret the aims and objectives of the Brunei history curriculum within their classroom practice. The present study showed that history teachers (in this study) do not have sufficient understanding what the curriculum wants the students to achieve. This may have implications to the quality of the teaching and learning of history. This issue should be considered and taken into account seriously. The findings in this study may serve as a preview of what was expected before the recent educational reform in Brunei. Within the present reform itself, there may be room for further improvement. Teacher educators especially those specializing in social studies (in the primary and lower secondary levels) and history (in the upper secondary and pre-university levels) also have a great responsibility to ensure that their courses can help teacher candidates to acquire appropriate and adequate basic knowledge of the curriculum matter in the field of history education. 


\section{References}

Altbach, P. G., Arboledo, A. A., \& Gopinathan,S. (Eds.). (1985). Publishing in the third world: Knowledge and development. New Hampshire: Heinemann Books.

Barton, K. C. (2005). Primary sources in history: Breaking through the myths. Phi Delta Kappan, 86(10), 745-753. http://www.jstor.org/stable/20441899

Bierman, P., Massey, C., \& Manduca, C. (2006). Reconsidering The Textbook. Eos, Transactions American Geophysical Union, 87(1), 306. http://dx.doi.org/10.1029/2006EO310004

Curriculum Development Department (CDD). (1990). History syllabus for upper primary. Ministry of Education, Brunei Darussalam.

Curriculum Development Department (CDD). (2002). Sejarah bagi sekolah rendah negara Brunei Darussalam. Ministry of Education, Brunei Darussalam.

de Oliveira, J. M., Camacho, M., \& Gisbert, M. (2014). Exploring student and teacher perception of e-textbooks in a primary school. Comunicar, 21(42), 87-95. http://dx.doi.org/10.3916/C42-2014-08

Harber, C. (1989). Politics in African education. London: MacMillan Publisher.

Hummel, C. (1988). School textbooks and lifelong education: An analysis of schoolbooks from three countries. Hamburg: UNESCO.

Mundia, L. (2010). Implementation of SPN21 curriculum in Brunei Darussalam: A review of selected implications on school assessment reforms. International Education Studies, 3(2), 119-129. http://dx.doi.org/10.5539/ies.v3n2p119

Nor, H. N. H. M., \& Shahrill, M. (2014). Incorporating the use of poster and oral presentations as an alternative assessment in the teaching of secondary mathematics. Proceeding of the $2^{\text {nd }}$ International Conference on Social Sciences Research (ISCCR 2014), June 9-10, 2014. Selangor, Malaysia: Koperasi KOKISDAR, Kolej Universiti Islam Antarabangsa Selangor, pp. 369-378.

Omar, N. A., Matarsat, S. R., Azmin, N. H., Wei, V. C. A., Nasir, M. M. M., Sahari, U. K. S., Shahrill, M., \& Mundia, L. (2014). The ideal psychology teacher: Qualitative analysis of views from Brunei GCE A-Level students and trainee psychology teachers. Asian Social Science, 10(12), 184-194. http://dx.doi.org/10.5539/ass.v10n12p184

Salam, N. H. A., \& Shahrill, M. (2014). Examining classroom interactions in secondary mathematics classrooms in Brunei Darussalam. Asian Social Science, 10(11), 92-103. http://dx.doi.org/10.5539/ass.v10n11p92

Santhiram, R. (1997). Curriculum material for national integration in Malaysia: Match or mismatch? Asia Pacific Journal of Education, 17(2), 7-17. http://dx.doi.org/10.1080/02188799708547758 


\section{Macrothink}

International Journal of Education ISSN 1948-5476 2014, Vol. 6, No. 2

Shahrill, M. (2009). From the general to the particular: Connecting international classroom research to four classrooms in Brunei Darussalam (Unpublished doctoral dissertation). University of Melbourne, Melbourne, Australia.

Wahid, N. A., \& Shahrill, M. (2014). Pre-university students' engagement towards the learning of mathematics. Proceeding of the $2^{\text {nd }}$ International Conference on Social Sciences Research (ISCCR 2014), June 9-10, 2014. Selangor, Malaysia: Koperasi KOKISDAR, Kolej Universiti Islam Antarabangsa Selangor, pp. 379-388.

Wakefield, J. F. (1998). A brief of history textbooks: Where have we been all these years? Paper presented at the Meeting of the Text and Academic Authors, St. Petersburg, FL, June 12-13, 1998.

Yong, B. C. S. (2010). Can students read secondary science textbooks comfortably? Brunei International Journal of Science and Mathematics Education, 2(1), 59-67.

\section{Copyright Disclaimer}

Copyright for this article is retained by the author(s), with first publication rights granted to the journal.

This is an open-access article distributed under the terms and conditions of the Creative Commons Attribution license (http://creativecommons.org/licenses/by/3.0/). 